\title{
Stabilization Policies and Employment
}

EAL OUTPUT declined and the unemployment rate rose during 1970 . The restrictive monetary and fiscal policies initiated in late 1968 had an impact on aggregate demand which affected output more than prices. Moderately stimulative monetary and fiscal policies were initiated in early 1970. The rate of increase in prices has stopped accelerating. However, a large expansion in aggregate demand could revive anticipations of rapid inflation. The current policy problem is to encourage a rate of growth in aggregate demand that is consistent with the most desirable combination of growth in output and employment and reductions in the rate of inflation.

\section{Recent Monetary and Fiscal Developments}

The decisions to initiate moderately stimulative monetary and fiscal policies in early 1970 were influenced by the decline in overall economic activity in late 1969. Industrial production declined in the last two quarters of 1969 , and real output fell during the fourth quarter, but unemployment did not begin to rise until early 1970. Inflation continued to be a problem for the economy throughout 1969. In fact, prices rose faster in 1969 than in the previous year. The objectives of stabilization policies initiated in early 1970 were to place downward pressure on the rate of price advance while reversing the pattern of falling output.

\section{Whantwe Dewhomens}

The money supply has grown since December 1969 after almost no increase in the previous two quarters. Between December 1969 and May 1970 the money supply rose at a 6.7 per cent rate, and from May 1970 to January 1971 at a slower 4.2 per cent rate. Over

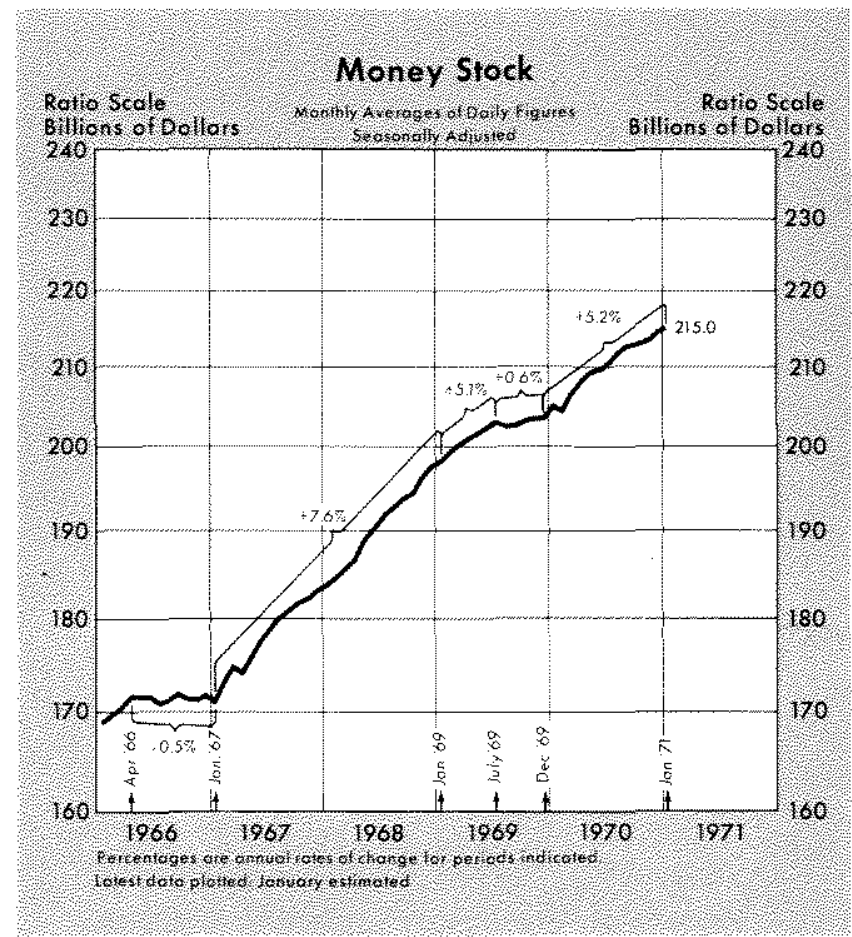

the 13-month period ending January 1971, the money stock increased at a 5.2 per cent rate.

The pattern of growth and decline in time deposits at commercial banks has been dominated in recent years by the relations between interest rates on competing assets and the interest ceilings on time deposits. The interest ceilings on large short-term certificates of deposit were more than 2 percentage points below 3-month Treasury bill rates in December 1969. Interest rates on competing assets had risen relative to the interest ceilings on time deposits during the previous year, and time deposits had consequently declined 5 per cent during the 12 -month period ending 


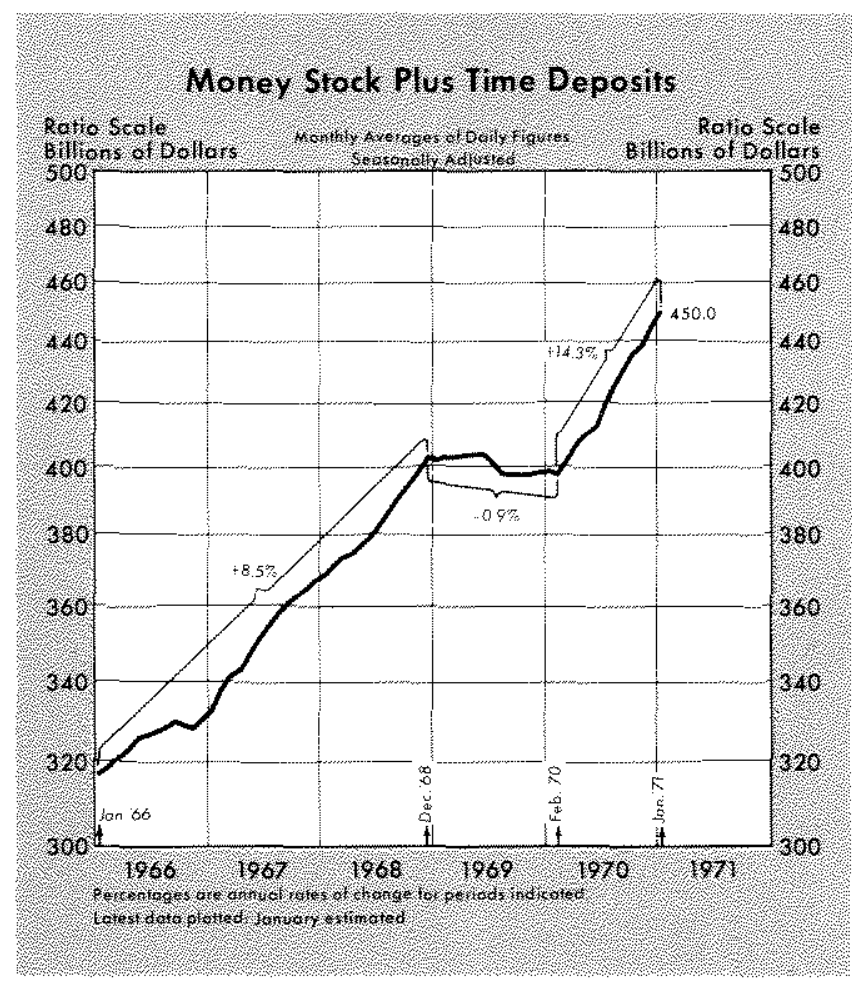

December 1969. Interest ceilings on time deposits were raised in January 1970, and interest ceilings on large short-term certificates of deposit were suspended in June. Not only were banks consequently able to pay higher interest rates than previously on time deposits, but also the interest rates on competing shortterm rates fell during 1970. Time deposits grew at a 23.6 per cent annual rate between February and January 1971 .

The growth in both time and demand deposits during 1970 allowed banks to increase their loans and investments, ${ }^{1}$ which grew at a 9.3 per cent annual rate between February and December 1970, compared with less than a one per cent rate from May 1969 to February 1970. The demand for bank loans was lower in the last half of 1970 than in 1969. Consequently, banks used their funds to increase holdings of investments, which had declined at about a 7 per cent annual rate during the 14 months ending February 1970. While loans rose at a 4.7 per cent annual

\footnotetext{
Bank funds obtained from nondeposit sources, such as Eurodollar borrowings and commercial paper sold through a bank's holding company or affiliate, also affect the capacity of banks to increase loans and investments. Banks began to reduce their Eurodollar borrowing in late 1969 and continued to do so in 1970. Bank-related commercial paper expanded in late 1969 , and then began to decline in August 1970. Reserve requirements were placed on bank-related commercial paper in August and certificates of deposit had again becone a source of funds. Total nondeposit sources of bank funds remained essentially unchanged during the first two quarters of 1970 and declined in the second half.
}

rate, investments increased at a 20.2 per cent annual rate during the 10 -month period ending December 1970.

Due to the general decline in the demand for loans relative to the supply, there has been a sharp decline in all short-term market interest rates during the past 13 months. The prime rate was reduced, in eight steps, from 8.5 per cent in March 1970 to 6 per cent in January 1971. The 3-month Treasury bill rate fell from a recent peak of 7.87 per cent in January 1970 to 4.20 per cent in late January 1971, and the yield on 4- to 6-month commercial paper fell from 8.78 per cent to 4.55 per cent in the same period. The yield on the highest-grade seasoned corporate bonds declined from a recent high of 8.5 per cent in June 1970 to 7.20 per cent in late January 1971.

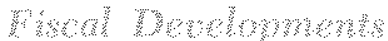

The high-employment Federal budget fell from about a $\$ 10$ billion surplus during the year ending in the first quarter of 1970 to a surplus at an average annual rate of about $\$ 5.7$ billion in the last three quarters of 1970. Major changes in Federal expenditures were increases in social security benefits and Federal pay increases retroactive to January. Major changes in Federal tax policies were the reduction in the surtax in January and July. In terms of the high-employ. ment budget, fiscal policy during the last three quarters of 1970 was slightly less restrictive than the budget policy in 1969 and early 1970, but was more restrictive than from mid-1965 to the end of 1968 when there was a deficit.

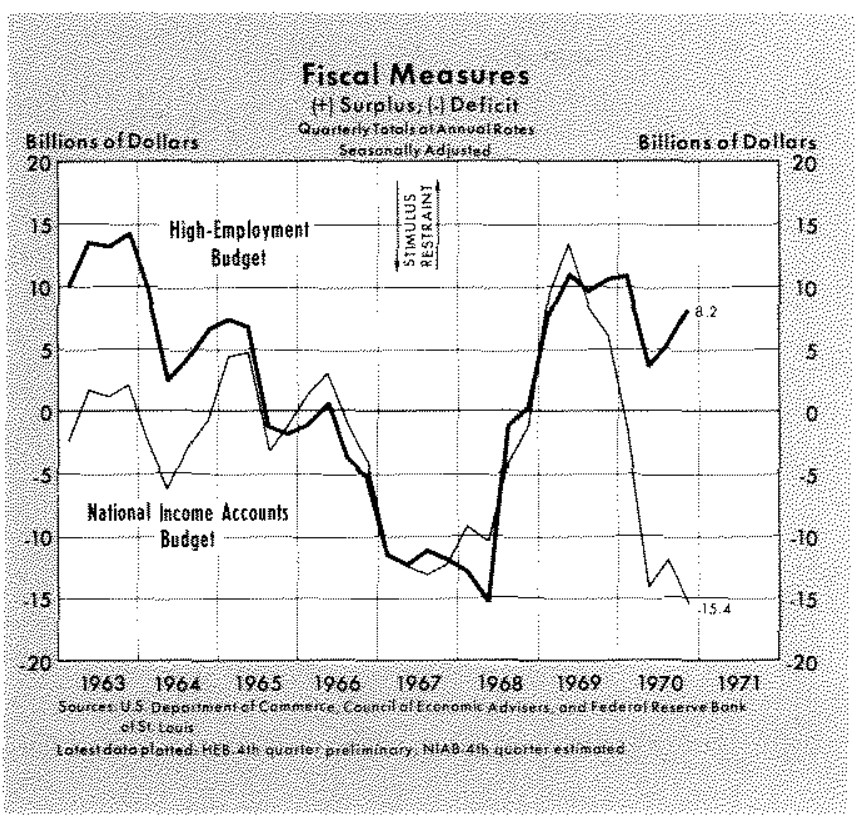


The Federal budget on a national income accounts (NIA) basis moved from a $\$ 9.3$ billion surplus in calendar 1969 to a deficit at an annual rate of about $\$ 13.8$ billion in the last three quarters of 1970 . The budget deficit during the last three quarters of 1970 was due primarily to the fall of tax revenues below what they would have been at full employment. This recent NIA budget deficit is a little larger than the deficit of 1967, but as a per cent of potential GNP is slightly less.

Budget plans for calendar 1971 indicate a 9 per cent expansion of Federal expenditures (NIA basis) over 1970. This increase compares with an 8 per cent ad. vance in 1970 and an average rate of increase of 12 per cent from 1965 to 1969 . Adjusting these expenditures to a high-employment basis and combining them with an estimate of revenues at high employment yields a high-employment surplus of about $\$ 7$ billion for calendar 1971. This estimate would be about the same as in 1970 , suggesting that the economic impact of budget plans for 1971 is little changed from 1970 .

\section{Spending and Prices}

Total spending increased 4.1 per cent from the fourth quarter of 1969 to the fourth quarter of 1970 ; the annual rate of growth in total spending in the first three quarters of 1970 was 4.8 per cent, and then 2.2 per cent during the fourth quarter. The relatively small fourth quarter growth may be attributed partially to the General Motors strike. Real output fell about 1 per cent from the fourth quarter of 1969 to the fourth quarter of 1970 ; it declined at a 0.3 per

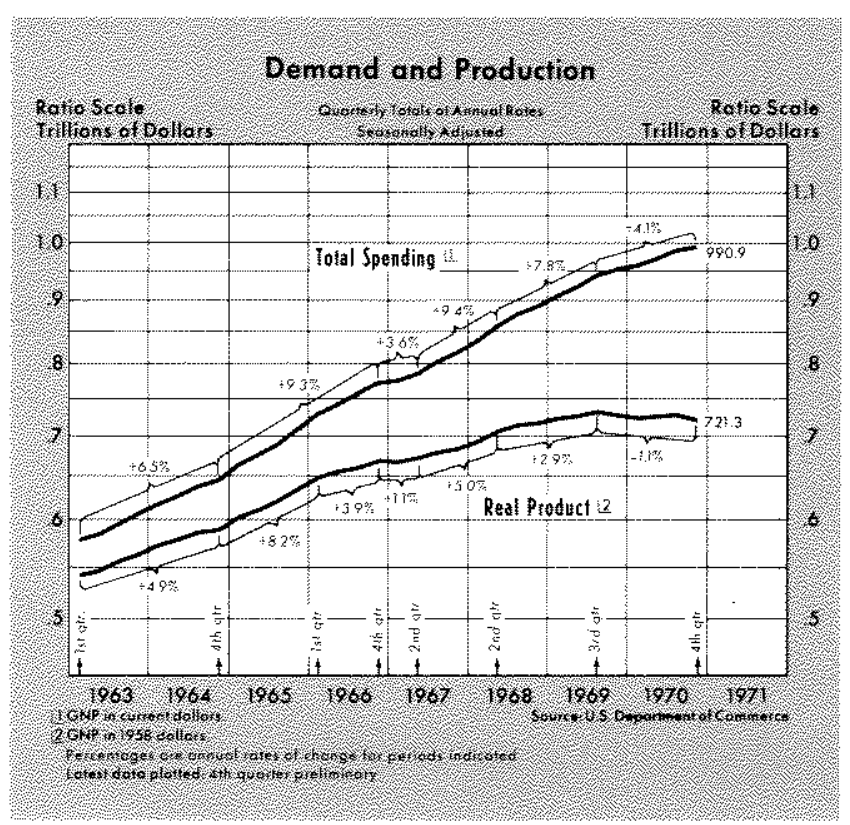

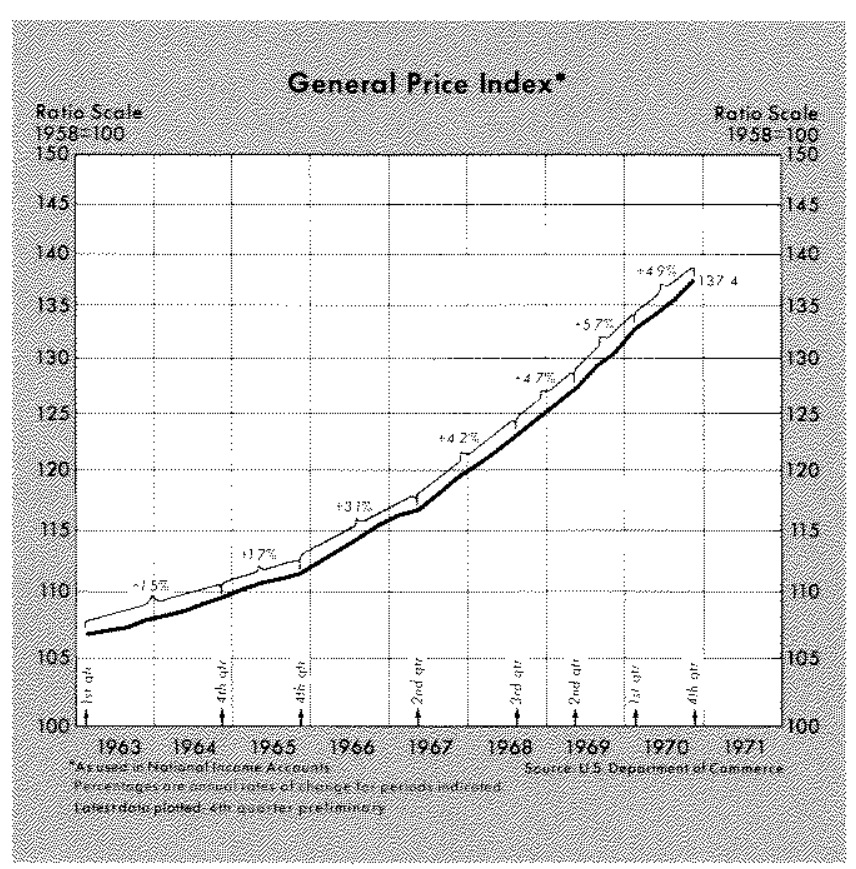

cent annual rate during the first three quarters of the year, but at a 3.3 per cent annual rate in the fourth quarter.

Inflation continued to be a problem during 1970 , but the rate of increase in prices slowed a little. The GNP implicit price deflator increased at an annual rate of 5.3 per cent from the fourth quarter of 1968 to the first quarter of 1970 , and at a 4.9 per cent rate during the last 3 quarters of 1970 . The pattern of decline in the rate of inflation was interrupted by the 5.7 per cent annual rate of growth of the GNP deflator in the fourth quarter of 1970. A portion of the fourth quarter rise in the GNP implicit price deflator was due to the price increases in the automobile industry. Consumer prices increased at a 5.3 per cent annual rate from March to December 1970 , compared with a 6.1 per cent rise in the 12 -month period ending March 1970.

\section{Employment}

The unemployment rate was at the relatively low level of 3.5 per cent in December 1969. By mid-1970 the rate had risen to about 5 per cent, and by December 1970 to 6 per cent, the highest rate since late 1961. Some amount of unemployment is to be expected in a changing economy because of people searching for jobs. Even in the tight labor market of 1969 , the average length of time between jobs was about 8 weeks and rose to just over 9 weeks by late 1970. But a rise in the unemployment rate from 3.5 to 6 per cent indicates that some important changes have 
taken place in the demand for or supply of labor, or both.

The rise in employment during 1970 was not fast enough to absorb the expansion in the labor force. Although civilian employment was about 730,000 higher in 1970 than in 1969 , unemployment rose because the civilian labor force increased about 2 million in the past year. The 320,000 reduction in armed forces personnel, and the continued rise in the labor force participation rate for women in the past year, contributed to the rise in the civilian labor force.

The unemployment rate is used as an index of labor capacity utilized and, quite often, as an indicator of the economic welfare of the society. The civilian labor force, the measure of potential labor input used in calculating the unemployment rate, includes persons who are employed or actively seeking employment. If persons who have not been actively seeking employment begin to do so, the unemployment rate can rise with no change in the demand for labor. If unemployed persons become discouraged in their search for jobs and drop out of the labor force, capacity utilization can appear to rise with no change in the demand for labor.

Another measure of potential labor input is the total population of working force age (16-64). Unemployed persons remain a part of this potential labor input whether or not they actively seek employment. The corresponding index of labor capacity utilized is total civilian employment as a per cent of the working force age (16-64) population.

The per cent of the working force age population employed has remained high during the past year compared with other periods. Nearly 64 per cent were employed in late 1970 , down from a peak of 65 per cent in early 1970 but larger than at any time during the 1950's and 1960's before 1966.

The impact of stabilization policies on employment is a reflection of their impact on total output. Real output declined slightly during the past year, and employers shifted their demand for labor downward. Employment did not expand as fast as potential labor input, measured as either the civilian labor force or the working force age population. Stabilization policies also influence the types of job opportunities available. The recent employment situation reflects to some extent the problems workers are having in moving from declining to expanding industries.

Monetary policy actions affect employment by influencing the aggregate demand for output and the anticipated future demand for output. ${ }^{2}$ The linkages

2Monetary actions may also affect the supply of labor. See "Population, the Labor Force, and Potential Output; Implications for the St. Louis Model" in this Review, pp. 15-23.

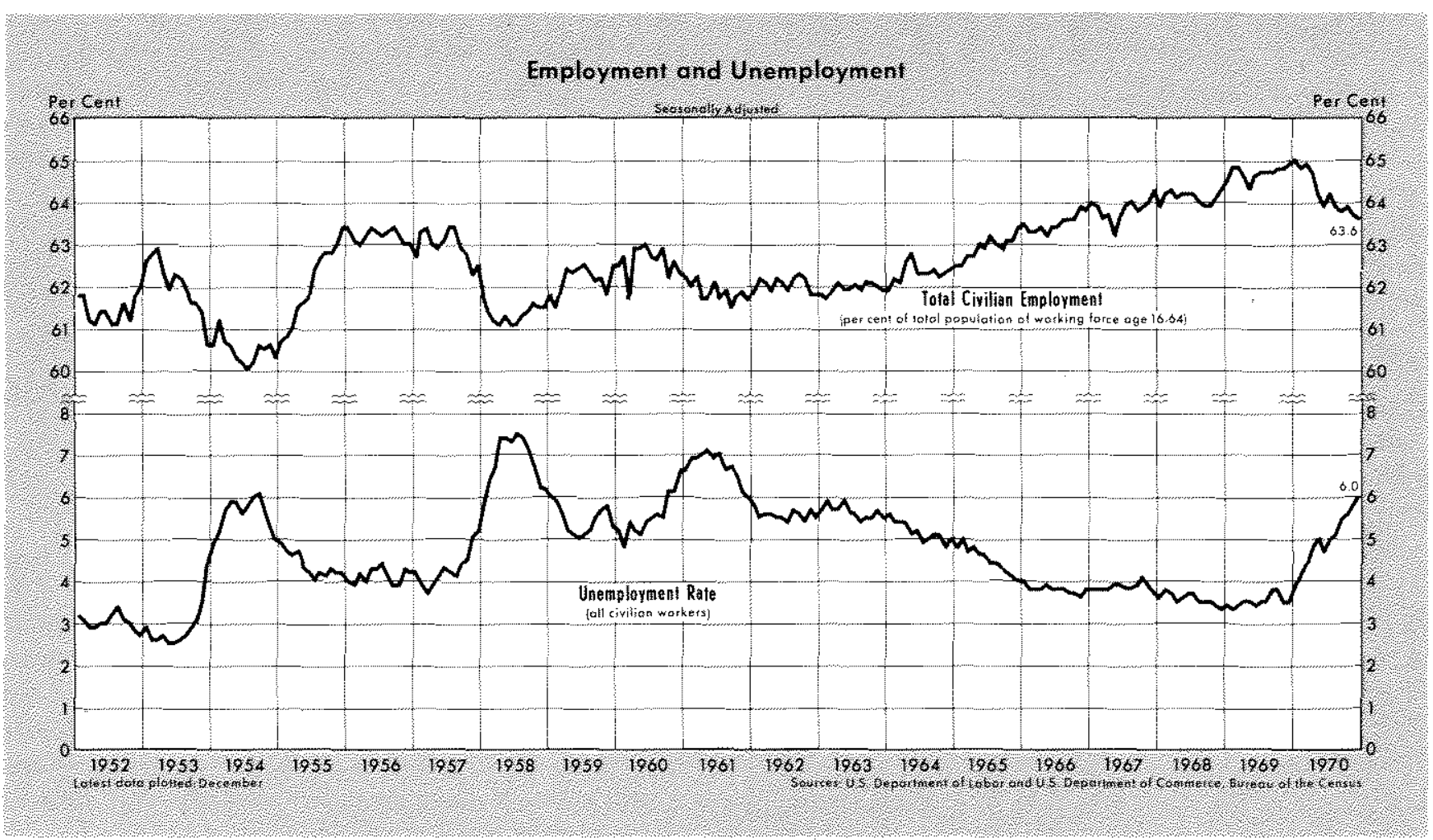


between monetary policy actions and employment begin with Federal Reserve decisions to influence some key economic variables, such as output, employment or prices. Short-run effects of monetary expansion are reduced interest rates on bank loans and increased prices of securities and equities. The in. crease in the money supply temporarily increases aggregate wealth until the prices of goods are bid up. Consumers and investors respond to the changes in interest rates and wealth by increasing their demand for output, and firms correspondingly increase their demand for labor. Consumer tastes and technology determine what type of job opportunities are made avallable.

Fiscal policy affects employment directly by creating or eliminating job opportunities in the Federal Government or in industries producing output for the Federal Govemment. Fiscal policy affects employment indirectly by its influence on private spending. During some period of time workers adjust their skills to the available employment opportunities. Changes in the types of employment opportunities in the private sector due to changes in consumer tastes and technology usually come gradually, and workers can adjust to these changes with a small amount of unemployment. The long-term trend of a larger share of employment in service industries and a smaller share in manufacturing is an indication of a gradual shift in the types of job opportunities. Changes in the types of job opportunities directly related to Federal Covernment expenditure have been more abrupt during certain periods.

The Federal Government reduced defense expenditures from an annual rate of $\$ 78.8$ billion in the fourth quarter of 1969 to an annual rate of $\$ 74.6$ billion in the fourth quarter of 1970 , a 5.3 per cent decrease. The Armed Forces were reduced about 400,000 and civilian employment in the Department of Defense was reduced about 100,000 between late 1969 and the end of 1970. Civilian employment in defenserelated industries declined by an estimated 600,000 during the past year. ${ }^{3}$

The estimated 1.1 million jobs eliminated by cuts in defense expenditures were approximately 1.4 per cent of the total civilian labor force at the end of 1970 . Even if there had been no decline in the aggregate demand for labor during the past year, such a large reduction in the number of jobs in one industry would

3Economic Report of the President (Washington: United States Government Printing Office, 1971), pp. 43 and 44. probably have increased unemployment temporarily while the workers looked for jobs in other industries.

The adjustment problems for former employees of defense-related industries are complicated by the heavy concentration of defense-related industries in the Pacific Coast states. About 35 per cent of the employment reductions in defense-related manufacturing industries between December 1967 and June 1970 were in California. The best alternative job for many of the displaced workers may be in another part of the country. The search for jobs in industries other than defense is made more difficult by having the defense expenditure cuts come during a period in which overall real economic activity is expanding slowly or not at all.

Professional and technical people appear to be bearing a larger share of the unemployment during the past few quarters than they have in other periods. Their problems are partially the result of the cuts in defense expenditures. About 6 per cent of all professional and technical workers were employed in defense-related industries in the fiscal year 1968. The number of unemployed professional and technical people increased about 58 per cent in 1970, compared with a 44 per cent increase in overall unemployment. The unemployment rate among professional and tech. nical workers rose to 2.5 per cent by the fouth quarter of 1970. The unemployment rate for these workers has been larger relative to the overall unemployment rate during the past few quarters than in other periods. The ratio of these two unemployment rates did not appear to have a cyclical pattern during the $1960-61$ recession.

\section{Summary}

Moderately stimulative monetary and fiscal policies were initiated in early 1970. The high-employment budget surplus was smaller in the last three quarters of 1970 than in the preceding year. Short-term interest rates declined during 1970 , and long-term rates declined during the second half.

Total spending increased 4.1 per cent and real output fell about 1 per cent from the fourth quarter of 1969 to the fourth quarter of 1970 . The slowdown in economic activity in the fourth quarter can be attributed partially to the automobile strike. The rate of increase in prices appears to have slowed in 1970 , but the relatively large rate of increase in prices in the fourth quarter interrupted this pattern of decline in the rate of inflation. 
Employment increased in 1970 but not as rapidly as the labor force. The unemployment rate increased from 3.5 per cent to 6 per cent from December 1969 to December 1970. The 6 per cent unemployment rate was the highest since late 1961 . The rate of labor capacity utilization, measured as the per cent of the working force age population employed, remained relatively high during the past year. Large cuts in defense expenditures during the past year have eliminated many jobs in the defense industry. The recent employment situation reflects not only the slight decline in real output but also problems of the former defense industry employees in finding jobs in other industries. 